\title{
TRANSPARENCY IN MANAGERIAL PRACTICES AND AFFECTIVE COMMITMENT
}

\author{
Kandiah Jenat Bratley \\ Deputy Director of Education, Northern Province, \\ kjbratley@gmail.com \\ *Shanthakumary Mahenthiran Aloysius \\ Department of Human Resource Management \\ University of Jaffna, \\ shanthamahenthiran@yahoo.com
}

\begin{abstract}
The objective of this study was to investigate the relationship between employees' perception of transparency in management and their affective commitment by focusing on four dimensions of management transparency: openness, accountability, integrity and participation. Two independent surveys type studies were conducted to establish the validity of the instrument developed for the purpose, and to empirically examine the hypothesized relationship using 850 randomly selected teachers in Northern Province. Findings revealed that the relationship between employees' perception of transparency and affective commitment was significantly and strongly correlated. It was also identified that the components of transparency such as openness, accountability integrity and participation explain the variations in affective commitment. The study recommended that a comprehensive strategy needs to be designed to enhance the level of managerial transparency among the Education Authorities.
\end{abstract}

Keywords: transparency; affective commitment; education authorities; openness; accountability 


\section{Introduction}

Affectively committed employees contribute to higher productivity and lower cost of production and thus give their organizations crucial competitive advantages (Vance, 2006). Therefore, it is very necessary to adapt appropriate strategies to enhance employees' affective commitment to their role and the organization. Employee commitment depends on how satisfied they are with the leadership of the organization (Taylor, 1998) and this can be attributed to the relationship between the management of the organization and the employees. Major et al. (1995) and Lee (2001) indicated that the relationship between management and employees is positively correlated with organizational commitment. Several studies have shown that employees' perception of being considered important and being empowered will increase their level of emotional attachment to the organization (Allen \& Meyer, 1990; Liden et al., 2000; Janssen, 2004; Chan, 2004). Sharing information and involving employees in decision making processes such as defining work objectives, specifying how to achieve them and setting stretch targets are necessary means of empowering employees (Carter, 2009). When employees are able to see the same information top managers see, their trust and loyalty develop - and both are vital to long term success. Managerial transparency has been found to have some influence on employees' attitude (Bloomfield \& O'Hara, 1999); and employees' perception of transparency is proved that it has a positive effect on employee trust (Rawlins, 2008). Hence, the literatures suggest that there may be relationship between employees' perception of managerial transparency and their affective commitment.

Generally, public sector organizations in Sri Lanka maintain secrecy in their employees related activities including hiring, transfer and others. A large number of employees employed in the education sector as the principal sector for hiring graduates of public Universities. This sector provides educated personnel for the labour market of Sri Lanka. Organizational commitment of the teachers affects quality of students and account largely for the productivity of the system. Teachers in Sri Lanka expect reasonable transparency in managerial decision making (Bratley \& Shanthakumary, 2017). Shanthakumary (2019) found that majority of the graduate teachers try to change their job as they want to be in a better position than the present. There are many articles published in the local newspapers 
regarding the promotion and the transfer related matters (DailyFT, 2020). Especially they pointed out partiality in the decision making. At this juncture, the study tries to find to what extent transparency in managerial practices affect affective commitment of teachers.

Therefore, the aim of this paper is to empirically identify the relationship between transparency in managerial practices and affective commitment of the employees in public education sector. In this regard, survey type quantitative studies were done with government employees serving as teachers in public schools managed by the Provincial Education Authorities of Northern Province, Sri Lanka.

\section{Transparency and Affective Commitment}

The study on organizational transparency has been a growing field and considerable number of formal studies, empirically examining the relationship between transparency and organizational outcomes, have taken place in the past two decades. These studies employed various models to demonstrate transparency. However, still there is a vacuum for universally recognized model to illustrate this construct. Rawlins (2008), representing almost all the previous models, presented a four-dimensional model of transparency. The components of this model included "information that is truthful, substantial and useful; participation of stakeholders in identifying the information they need; accountability that necessitates the organization to report objectively of its activities and policies; and secrecy which is the reverse measurement of openness." Similarly, Kim (2009) employed a three-dimensional model to study transparency in local governance setting. The dimensions of this model were openness, participation and integrity. The openness means the availability of government information for scrutiny, laws and rules ensuring citizen's right to know, media freedom, communicating and knowledge sharing processes. The participation connotes involving the representatives in policy development processes. The integrity conveys the theme of "incorruptibility which requires that holders of public office avoid placing themselves under financial or other obligation to outside individuals or organizations that may influence them in the performance of their official duties" (Cheema, 2003).

The analysis of these two models in consideration of other studies which contributed to the construction of transparency models, leads to the identification 
of the key components of transparency. The openness component of transparency can be explained as acting and taking decisions in an open and transparent manner; it includes ensuring of NOT withholding information from the beneficiaries unless there are clear and lawful reasons for so doing (Committee on standards in public life, 1995). Rawlins (2008) recognized the reverse of openness as secrecy and defined it as a measure of lack of openness, or attempts at secrecy. According to him the secrecy dimension means deliberately sharing part of the story, using technical jargon or languages that make the understanding difficult, or disclosing only when required or requested. This can be further illustrated by Dapko (2012)'s example of the situation in which a salesperson answers all of the questions of customer and he /she perceive him to be transparent; but imagine that there are questions which customer has not asked but important for decision making and if the salesperson did not provide the information since the customer did not ask, there is the element of secrecy in this transaction. Researchers have observed that "forthright exchange" (Plaisance, 2007), and "freely" volunteering information (Baker, 2008) are essential for non secrecy. Schnackenberg \& Tomlinson (2016) examined the existing literature and found that three components of transparency are common in many writings such as disclosure, clarity and accuracy and in line with the early writings of Schnackenberg (2009). He stated that the perception of information transparency or openness is determined by three important elements: Disclosure: (i.e., the quantity of information made available to the interested parties at the correct time), Clarity: (i.e., the degree to which the information is comprehensible depending on the media, linguistic factors, contextual sensitivity, presentation mechanism and noise management etc), and Accuracy: (i.e., the degree to which information is perfect as perceived by the sender). Disclosure is defined as the perception of relevant information received in a timely manner (e.g., Bloomfield \& O'Hara, 1999; Williams, 2008). Pirson \& Malhotra (2011), for instance, measured transparency as a function of stakeholder's perception that the organization disclosed all relevant information genuinely. Clarity denotes the seamless transfer of the intended meaning of the information from sender to receiver (Watzlawick, Beavin, \& Jackson, 1967). This indicates the perceived level of explicitness and unambiguousness of information. Several literatures have depicted clarity as one of the vital aspects of information transparency (e.g., Flood et al., 1999; Potosky, 2008). Accuracy is defined as the perception that information is correct to the extent possible given the relationship between sender 
and receiver (Burnette \& Dollar, 1989). The importance of accuracy stems from the perspective that if the information is deliberately contrived or distorted, it cannot be considered as transparent (Walumbwa et al., 2011). In addition to this, several studies have argued that accuracy is pivotal to transparency (Vorauer \& Claude, 1998; Granados et al., 2006). Akhigbe \& Martin (2006) pointed out that inaccurate disclosures prompt corporate scandals and leads to reduction in corporate transparency. Hence, if the term openness can be used in a more comprehensive way to encompass all the above elements of openness including its reverse measures it can be considered as a vital component of transparency. Accountability is another important component of transparency identified by Rawlins (2008).

The Global Reporting Initiative (GRI, 2006) defined accountability as disclosing both favorable and unfavorable information and not attempting to unduly influence the stakeholder's interpretation of the information. Rawlins (2008) held that transparent organizations should be accountable for their actions and decisions. This means that managers in transparent organizations should be accountable for their decisions and behaviors (Rawlins, 2008). Integrity is the next important component as identified by Kim (2009). Cheema (2003) also identified integrity as an important component of transparency in local governance. According to Cheema (2003) "integrity requires that holders of public office avoid placing themselves under financial or other obligation to outside individuals or organizations that may influence them in the performance of their official duties." Ball (2009) noted that transparency and integrity are closely related constructs. Integrity can also be defined as incorruptibility or observing fairness of rules, procedures, and resource allocation (Cheema, 2003; Kim, 2009). According to Kim (2009) and Rawlins (2008) participation is another key component of transparency. Rowe \& Frewer (2005) defined citizen participation as 'the practice of involving members of the public in the agenda-setting, decision-making, and policy-forming activities of organizations/institutions for policy development.' According to Ginsberg (2012) transparency means more than disclosure of government information. It includes access, comprehension, and use of information by the public. Disclosing clear accurate information is not enough for transparency, stakeholders' involvement is also necessary. Summarily, transparency can be represented by a four-component model; the components are openness, accountability, integrity and participation. 
Employee commitment has been studied as one of the key aspects which describes the affection between employee and organization. Considering the importance of employee commitment to the organization, behavioral scientists have paid more attention on this concept (Mowday et al., 1982). However, the assumption of its impact on organizational performance also steadily increased its popularity (Suliman and Iles, 2000). Hence, an impressive amount of research has been conducted on this field. Many studies have proved that the success of the organization highly depends on employee's commitment (Holden, 1998; Shore, \& Martin, 1989; Meyer et al, 1989; Meyer, Allen, \& Smith, 1993; Meyer et al, 2002; Siders, George, \& Dharwadkar, 2001; Jaramillo, Mulki, \& Marshall, 2005). The construct of employee commitment has been well illustrated by the threecomponent model of Mayer and his colleagues (Mathieu \& Zajac, 1990; Meyer \& Allen, 1991; Meyer \& Allen, 1997; Meyer et al., 2002); it incorporates affective, continuance and normative commitments as its dimensions. Mercurio (2015) pointed out that affective commitment can be the core of organizational commitment based on the support of conclusive empirical evidences. It has been generally agreed that employees' emotional bond to an organization is the affective commitment which manifests itself through their sense of belongingness, their identification with and involvement in organization's activities (Mathieu \& Zajac, 1990; Meyer \& Allen, 1991; Mowday, Porter \& Steers, 1982). These employees have strong willingness to pursue the organizational goals and a desire to remain with the organization (Meyer \& Allen, 1991; Mowday, Porter \& Steers, 1982). Affective commitment also represents the process by which employee's personal goals and the goals of the organization become congruent (Hall, Schneider \& Nygren, 1970). Affective commitment leads to higher productivity (Meyer et al., 1989); it generates positive work attitudes among employees (Allen \& Meyer, 1996); and it enhances citizenship behaviors for positive results (Meyer \&Allen, 1991).

Researchers' curiosity on transparency and organizational commitment is now growing. They try to find out how transparency affect employees in the organizations. Further, stated that the association between transparency and commitment is unclear (Maxwell, 2017). However, his analysis revealed a strong positive relationship between both of the concepts. 


\section{Methodology}

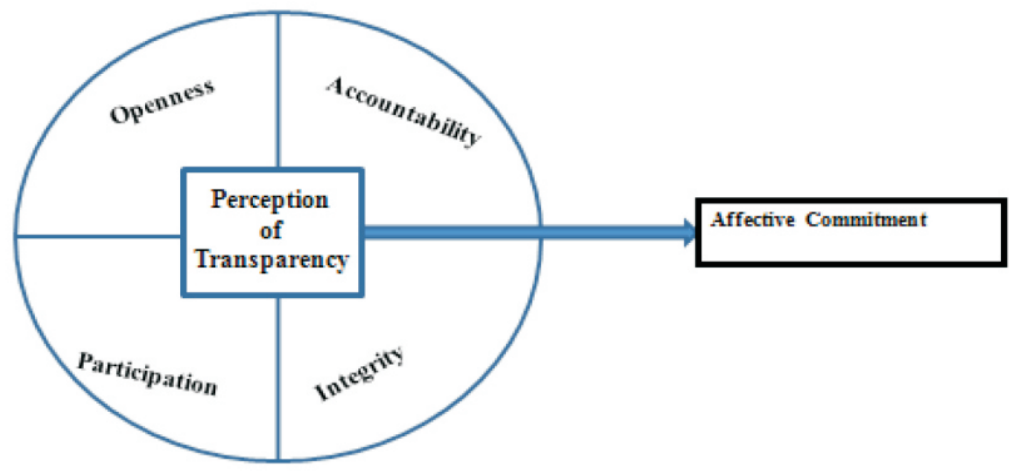

Independent Variable

Dependent Variable

Figure 1. Conceptual framework of the study

\subsection{Hypotheses}

The current study focuses on affective commitment of teachers to do their teaching profession as it attempts to capture one's genuine desire to perform his/her duties and embodies more than mere compliance, but rather authentic attention, alignment, and effort related to performance.

Several studies have demonstrated that employees' affective commitment is determined by their perception of organizational practices. Bartlett (2001)'s study with 337 registered nurses showed that there is a relationship between employees' perception of organizational practices and their affective form of commitment. Allen \& Shanock, (2013) demonstrated based on a study done with 500 employees that their perception of organizational support is related to their affective commitment. Eisenberger, Fasolo, \& Davis-LaMastro (1990) reported the results of two studies that employees' perception of being valued, cared about and positive support by the organization is related to their affective commitment. Rhoades \& Eisenberger (2002) reviewed more than 70 studies and concluded that employees' perception of organizational support is positively related to affective commitment. Hence, in this context, it is argued that employees' perception of managerial transparency predicts affective commitment to their duties in that those with high perception levels of transparency perform better in their teaching profession compared with those with low perception levels of transparency. This argument leads to the following hypothesis: 
H1: There is significant relationship between employees' perception of transparency and affective commitment

\subsection{Study 1: The Scale Development}

Study 1 used exploratory factor analysis (EFA) and assessments of internal consistency reliability to empirically examine the factor structure and consistency validity of the items that emerged from literature review. Results led to the elimination of poorly loading items and items that were inconsistent to others.

\subsubsection{Sample and Procedure}

The sample for this study was drawn from employees serving as teachers in government schools managed by Provincial Council administration in the Northern Province of Sri Lanka. The respondents were 350 teachers selected based on random sampling. Two hundred and eighty-seven responded with $82 \%$ response rate. The sample had the following demographics: $73 \%$ Female, mean age of 35.6 years and 8.27 years average tenure in teaching profession. The 23 items for perception of transparency and 9 items for affective commitment derived from literature survey were administered to these employees. Responses were obtained on a five-point Likert-type scale anchored from 1 (strongly disagree) to 5 (strongly agree).

\section{Analysis}

Exploratory factor analysis (EFA) was conducted using principal axis extraction and a promax rotation. The eigenvalue greater-than-one test and a Scree test were used to determine the number of meaningful factors. The decision rule for judging that an item defined a factor was a loading greater than or equal to 0.40 with low cross-loadings (Towler \& Dipboye,2003). Tabachnick \& Fidell (1996) recommended using the Scree test to further discern the appropriate number of factors. They advocate selecting the number of factors at the point which the slope of the line between factors flattens or approaches zero. Coefficient $\alpha$-reliabilities were used to determine the internal consistency of the items defining a factor.

\subsection{Results and Discussion}

4.1.1 Perception of Transparency:

The KMO index was 0.905 which indicated that patterns of correlations are 
relatively compact and so factor analysis should yield distinct and reliable factors. Since the value is above $0.9 \mathrm{it}$ is confident that the factor analysis is appropriate for these data. Moreover, Bartlett test of sphericity was also highly significant ( $\mathrm{p}<$ 0.001 ) and therefore the factor analysis is appropriate. Results revealed four factors with eigenvalues greater than 1.0. Four items were dropped because they did not load adequately on any factor. The remaining 19 items were reanalyzed and generated a clean four-factor solution that collectively accounted for $64.7 \%$ of the variance. Loadings and a-reliabilities are shown in Table 1. Results of the factor analysis suggested four interpretable facets for the perception of transparency. This decision was further supported by the Scree test, as the line between factors flattened between the fourth and fifth factors. To explore this possibility, reliability analyses were rerun combining the items from each factor identified. The areliability for each factor is presented in Table 1.

\section{Table 1. Exploratory Factor analysis Results for Perception of Transparency (Study 1)}

\section{Items and factors}

Dimensions of Transparency

$\begin{array}{lllll}\alpha & 1 & 2 & 3 & 4\end{array}$

Factor 1- Openness 0.936

I feel management provides easy access to information

I feel management provides relevant information

I feel management provides adequate information

I feel management provides information in a timely fashion

I feel management provides accurate information

I feel management provides clear information

Factor 2-Accountability

I am confident of that the management wants to be accountable for its actions and decisions.

I am quite sure that management discloses information both favourable and unfavourable to itself.

I am convinced that the management is prepared to admit frankly when it has made mistakes or inappropriate decisions

I am quite sure management discloses true progress reports. 
Factor 3- Integrity

I am convinced that management observes fairness of rules, procedures and resource allocation in all activities

I believe holders of managerial positions perform their

official duties without any hidden motives

I am confident of that the management can be relied on to keep its promises

I trust that the management is guided by sound policies, principals and guidelines.

Factor 4- Participation

I know management bears the burden of helping me to identify the information I need and provides the same I know management values involving representatives of the employees in the agenda-setting, decision-making, and policy-forming activities.

I understand that management obtains feedback from employees like me about the quality of the information it reveals

I know management has established a proper mechanism to ensure a rightful participation of employees in management I trust management accepts criticisms from all stakeholders including myself

Source: Primary

\subsubsection{Affective Commitment:}

The KMO index was 0.916 which indicated that patterns of correlations are relatively compact and therefore factor analysis can be relied on yielding distinct and reliable factors. As the index value is above 0.9 it is confident that the factor analysis is appropriate for these data. Moreover, Bartlett test of sphericity (highly significant; $\mathrm{p}<0.001$ ) also indicates that factor analysis is appropriate. Results revealed one factor with Eigen values greater than 1.0. Three items were dropped because they did not load adequately on any factor. The remaining 6 items were reanalyzed and generated a clean one-factor solution that collectively accounted for $72.9 \%$ of the variance. Loadings and a-reliabilities are shown in Table 2. 
Results of the factor analysis suggested one interpretable facet for the affective commitment. This decision was further supported by the Scree test, as the line between factors flattened between the first and the second factors. To explore this possibility, reliability analyses were rerun combining the items. The $\alpha$-reliability for this scale was 0.925

\section{Table 2.Exploratory Factor analysis results for Affective Commitment}

\begin{tabular}{|c|c|c|}
\hline Items and factors & $\alpha$ & $\begin{array}{c}\begin{array}{c}\text { Dimension of } \\
\text { Affective } \\
\text { Commitment }\end{array} \\
1\end{array}$ \\
\hline Factor 1- Affective Commitment & 0.925 & \\
\hline I feel a strong sense of belonging to school education sector & & 0.900 \\
\hline I would be very happy to spend the rest of my career with school education & & 0.897 \\
\hline I feel emotionally attached to my teaching profession & & 0.914 \\
\hline My teaching profession has a great deal of personal meaning for me & & 0.601 \\
\hline I feel like "part of the family" in the education system & & 0.912 \\
\hline I really feel any problems in the general education sector are my own problem & & 0.854 \\
\hline
\end{tabular}

Source: Primary

\subsection{Study 2: Examining the Relationship}

Study 2 employed correlation and regression analysis to study the relationship between perception of transparency and commitment. For this study, data were collected from employees serving as teachers in government schools in the Northern Province of Sri Lanka. The developed tool was duly distributed to 500 teachers who were selected based on stratified random sampling. The response rate was $61 \%$. The sample had the following demographics: $68.5 \%$ Female, mean age of 37.2 years and 10.7 years average tenure in teaching profession.

The correlation analysis using revealed that all transparency components were strongly correlated among each other and all transparency components had strong positive correlation with affective commitment. Likewise, overall transparency also had positive statistically significant correlation with affective commitment. When the same data was subjected to standard regression analysis, it was found that about $94.4 \%$ of the variations in affective commitment in the province was explained by the linear combination of four components of transparency 
$(\mathrm{F}=1254.0, \mathrm{p}<0.001)$. The high $\mathrm{F}$ value and the low Sigma value suggested that these four independent variables were indeed different from each other and that they affect the dependent variable affective commitment in a different manner. Openness (Beta $=0.349)$, Accountability (Beta $=0.143)$, Integrity (Beta $=0.223)$ and Participation (Beta $=0.299$ ) had significant positive regression weights, indicating that they statistically significantly contributed to the prediction of affective commitment after controlling the other variables in the model. Accountability had a low contribution to the regression model. Even though all four components were strongly correlated with affective commitment Openness, Integrity, and Participation are more closely associated than Accountability, in the mindsets of the employees who participated in the study.

The stepwise multiple regression analysis showed that, at step four of the analysis, openness, integrity and participation entered into the regression equation and were significantly related to affective commitment with $\mathrm{F}(4,300)=1254.00, \mathrm{p}<.001$. The multiple correlation coefficient was 0.971 , and the regression equation for predicting affective commitment was:

Predicted affective commitment $=0.349$ Openness +0.223 Integrity +0.299 Participation +0.143 Accountability +0.045

Table 3: Predicting affective commitment using Regression analysis

\begin{tabular}{|rcc|cc|}
\hline & $\boldsymbol{\beta}$ & $\boldsymbol{S E}$ & $\boldsymbol{t}$-Value & Sig. \\
\hline Constant & .045 & .044 & 1.018 & .309 \\
Openness & .349 & .070 & 4.992 & .000 \\
Accountability & .143 & .069 & 2.081 & .038 \\
Integrity & .223 & .063 & 3.560 & .000 \\
Participation & .299 & .063 & 4.780 & .000 \\
\hline
\end{tabular}

$\mathrm{F}(4,300)=1254.0, \mathrm{p}<0.001, \quad \mathrm{R}=0.971, \mathrm{R}^{2}=0.944$ Adjusted $\mathrm{R}^{2}=0.943$ Source: Primary 


\section{Discussion}

The major concern of this study was to explore the relationship between employees' perception of transparency in management and their affective commitment and also was to explore deeply the relationships between the different components of employees' perception of transparency and the affective commitment. The research also focused on exploring the extent to what each component of employees' perception of transparency affect employees' affective commitment. The correlation studies indicated that there was a significant positive relationship between transparency and affective commitment. This explained that if the overall level of transparency perceived by the employees regarding the management practices is leant towards uphill, their level of affective commitment also tends to go up. The regression analysis also supported this finding. The openness component was found to be heavily influencing affective commitment followed by integrity, participation and accountability respectively. So it can be concluded that there is a significant relationship between employees' perception of transparency and affective commitment. This finding is in consistent with the existing theoretical knowledge about employee commitment. Literatures suggest that, even though other factors are involved, commitment to the organization is probably most reflective of how employees perceive about their management and its actions (Beheshtifar \& Heart, 2013; Ingram, 2009; Green, Anderson \& Shivers 1996; Nystrom, 1990; Settoon, Benet \& Liden, 1996; Mcfarlin \& Sweney, 1992). The Meta analysis by Meyer et al. (2002) ensured that perceived organizational support had strong positive correlation with affective commitment. Eisenberger et al. (1986) demonstrated this fact and argued that organizations which expect affectively committed employees should provide a supportive work environment. According to Rawlins (2008), a transparent management should provide information to employees to enable them to make informed decisions regarding their affiliation with the professional environment. Providing employees with necessary information to make informed decisions with respect to their organizational life is an important support an organization can give to its employees. Future research needs to examine the veracity of this proposition using different samples of employees from other sectors to find out the relationship between perception of transparency and commitment. 


\section{Conclusions}

The first exploratory factor analysis showed that the components of the transparency have adequate $\mathrm{KMO}$ and the reliability to proceed further analysis. The scale will be supportive to the future researchers who are interested in the same field. The results of the regressions provided strong evidence that the transparency in managerial practices influence on the affective commitment of the teachers in the Northern Province. The results of the regressions showed that the components of transparency are explaining $94.4 \%$ of the variance of affective commitment. The regressions also showed that openness component of transparency has stronger explanatory power in predicting the relationship between transparency and affective commitment. Openness, Participation and Integrity are the components of transparency that explained the most in the relationship between transparency and affective commitment.

\section{Practical Implication}

There is no study conducted in Sri Lanka regarding employees' expectation of managerial transparency and its outcomes. Public sector employees are criticized for their performance and the way they treat the customers. On the other hand, they face many issues due to the existing system in decision making. The current study addresses the expectation of employees and will imply need for transparent practices in managerial practices as a way to improve affective commitment of employees in public sector. The authors did not come across previous studies of Sri Lanka in relation to the topic, therefore, future researchers can examine different aspects of transparency in managerial practices and their outcomes to increase the knowledge base of the discipline. 


\section{References:}

Akhigbe , A., and Martin, A. D. (2006). Valuation impacts of Sarbanes-Oxley: Evidence from disclosure and governance within the financial services industry. Journal of Banking and Finance, 30(3), 989-1006

Allen, D. G., and Shanock, L. R. (2013). Perceived organizational support and embeddedness as key mechanisms connecting socialization tactics to commitment and turnover among new employees. Journal of Organizational Behavior, 34(3), 350-369.

Allen, N. J., and Meyer, J. P. (1990). The measurement and antecedents of affective, continuance, and normative commitment to the organization. Journal of Occupational Psychology.63(1), .1-18.

Allen, N. J., and Meyer, J. P. (1996). Affective, continuance, and normative commitment to the organization: An examination of construct validity. Journal of Vocational Behavior. 49(3), 252-276.

Baker, S. (2008). The Model of The Principled Advocate and The Pathological Partisan: A Virtue Ethics Construct of Opposing Archetypes of Public Relations and Advertising Practitioners. Journal of Mass Media Ethics, 23(3), 235-253.

Ball, C. (2009). What is Transparency. Public Integrity 11(4), 293-308.

Bartlett, K. R. (2001). The relationship between training and organizational commitment: study in the health care field. Human Resource Development Quarterly, 12(4), 335-352.

Beheshtifar, M., and Heart,B.H. (2013). To Promote Employees Commitment via Perceived Organizational Support. International Journal of Academic Research in Business and Social Sciences 3(1),306-313.

Bloomfield, R., and O'Hara, M. (1999). Market Transparency: Who Wins and Who LosesfiThe Review of Financial Studies.12(1), 5-35.

Bratley, K.J., and Shanthakumary, M.C.M.A. (2017). "Employees' Perception of Transparency in Management and Their Commitment: A Special Reference 
to Education Management", EPRA International Journal of Research and Development, vol. 2,no.7,78-84.

Brunett, M.J., and Dollar. A (1989). Business Communications: Strategies for Success Texas: Dame Publications.

Carter, J.D.T. (2009). "Managers Empowering Employees", American Journal of Economics and Business Administration 1(2),41-46.

Chan, Y. H. (2004). An ontological network approach to the study of antecedents, moderator, mediators and outcomes of psychological empowerment. Dissertation Abstracts. International Section A: Humanities and Social Sciences. 64(10-A),37-49.

Cheema, G. S. (2003) Strengthening the integrity of government: Combating corruption through accountability and transparency. In D. A. Rondinelliand G. S. Cheema (Eds.), Reinventing government for the twenty-first century: State capacity in a globalizing society. Bloomfield, CT: Kumarian Press.

Committee on Standards in Public Life (1995) Guidance: the 7 Principals of public life [Online] https://www.gov.uk/government/publications/the-7principles-of-public-life/the-7-principles-of-public-life--2

DailyFT, (26th may,2020). "Who is responsible for the parlous state of education in the Northern ProvincefiWho is to answerfi"

Dapko, J.(2012). Perceived Firm Transparency: Scale and Model Development, A dissertation submitted in partial fulfillment of the requirements for the degree of Doctor of Philosophy[Online]. Florida: Department of Marketing. College of Business. University of SouthFlorida. http://scholarcommons.usf.edu/cgi/ viewcontent.cgifiarticle $=5221$ andcontext $=$ etd.

Eisenberger, R., Fasolo, P., and Davis-LaMastro, V. (1990). Perceived organizational support and employee diligence, commitment and innovation. Journal of Applied Psychology 75(1), 51-59.

Eisenberger, R., Huntington, R., Hutchison, S., and Sowa, D. (1986). Perceived organizational support. Journal of Applied Psychology 71(3). 500-507. 
Flood, M et al. (1999). Quote disclosure and price discovery in multiple-dealer financial markets. Review of Financial Studies. 12(1), 37-59.

Ginsberg, W. et al. (2012). Government Transparency and Secrecy: An Examination of Meaning and Its Use in the Executive Branch. USA: Congressional Research Service.

Granados, N., Gupta, A., and Kauffman, R.J. (2010). Research Commentary-Information Transparency in Business-to-Consumer Markets: Concepts, Framework, and Research Agenda. Information Systems Research 21(2), 207-226.

Green, S., Anderson, S., and Shivers, S. (1996). Demographics and organizational influences on leader-member exchange and related work attitudes. Organizational Behavior and Human Decision Processes. 66(2),203-214.

GRI. (2006). Sustainability Reporting Guidelines, Version 3.0 [Online] Available from: https://www.globalreporting.org/resourcelibrary/G3-SustainabilityReporting-Guidelines.pdf

Hall, D. T., Schneider, B., and Nygren, H. T. (1970) Personal factors in organizational identification. Administrative Science Quarterly. 15(3),176190.

Holden, P. (1998). The Excellent Manager's Companion. Aldershot: Gower Publishing Limited.

Ingram, H.J. (2009). Organizational Transparency, Employee Perceptions, and Employee Morale: A Correlational Study. A Dissertation presented in partial fullfilment of the requirements for the degree doctor of Management in organizational leadership, University of phoenix, https://search. proquest.com/ openview/ 61770f8d05f65b0b75c54764162ea204/1fipqorigsite $=$ gscholarandcbl $=18750$ anddiss $=\mathrm{y}$

Janssen, O. (2004). The barrier effect of conflict with superiors in the relationship between employee empowerment and organizational commitment. Work and Stress. 18(1), 56-65. 
Jaramillo, F., Mulki, J.P., and Marshall, G.W. (2005). A meta-analysis of the relationship between organizational commitment and salesperson job performance: 25 years of research. Journal of Business Research. 58(6), 705714.

Kim, S. (2009). Management Strategy for Local Governments to Strengthen Transparency in Local Governance. Good Governance Research-1. United Nations: UNPOG Publication.

Lee, J. (2001) Leader - member exchange, perceived organizational justice, and cooperative communication. Management Communication Quarterly. 14(4), 574-589.

Liden, R. C., Wayne, S. J., and Sparrowe, R. T.(2000). An examination of the mediating role of psychological empowerment on the relations between the job, interpersonal relationships and work outcome. Journal of Applied Psychology. 85(3), 407-416.

Major, D.A., Kozlowski, S.W.J., Chao, G.T. and Gardner, P.D. (1995). “A longitudinal investigation of newcomer expectations, early socialization outcomes, and the moderating effect s of role development factors", Journal of Applied Psychology. vol 80, no.3, pp. 418-431.

Mathieu, J. E., and Zajac, D. M. (1990). A Review and Meta-analysis of the Antecedents, Correlates, and Consequences of Organizational Commitment. Psychological Bulletin.108(2), 171-194.

Maxwell, S. (2017). "Let's be clear": Exploring the Role of Transparency Within the Organization". Cornerstone: A Collection of Scholarly and Creative Works for Minnesota State University, Mankato.

Mcfarlin, D., and Sweeney, P. (1992). Distributive and procedural justice as predictors of satisfaction with personal and organizational outcomes. Academy of Management Journal, 35(3), 626-637.

Mercurio, A. Z. (2015). Affective Commitment as a Core Essence of Organizational Commitment: An Integrative Literature Review, Human Resource Development Review, 14(4),389-414. 
Meyer, J. P., and Allen, N.J. (1991) A three component conceptualization of organizational commitment. Human Resource Management Review.1(1), 6189.

Meyer, J. P. et al (1989). Organization commitment and job performance: It's the nature of the commitment that counts. Journal of Applied Psychology. 74(1), 152-156.

Meyer, J. P., Allen, N. J. and Smith, C. A. (1993). Commitment to Organizations and Occupations: Extension and Test of a Three-Component Conceptualization. Journal of Applied Psychology.78(4), 538-552.

Meyer, J.P., et al. (2002). Affective, continuance, and normative commitment to the organization: A meta-analysis of antecedents, correlates, and consequences. Journal of Vocational Behavior. 61(1), 20-52.

Mowday, R. T., Porter, L. W., and Steers, R. (1982). Employee-Organizational Linkages: The Psychology of Commitment, Absenteeism, and Turnover. San Diego, CA: Academic Press.

Nystrom, P. (1990). Vertical exchanges and organizational commitments of American business managers. Group and Organization Management. 15(3), 296-312.

Pirson, M., and Malhotra, D. (2011). Foundations of Organizational trust: What matters to different stakeholders fiOrganization science. 22(4), 1087-1104.

Plaisance, P. L. (2007). Transparency: An assessment of the Kantian roots of a key element in media ethics practice. Journal of Mass Media Ethics. 22(2-3), 187207.

Potosky, D. (2008). A conceptual framework for the role of the administration medium in the personnel assessment process. Academy of Management Review, 33 (3), 629-648.

Rawlins, B. L. (2008) Measuring the relationship between organizational transparency and employee trust. Public Relations Journal 2(2),1-22 http://www.prsa.org/Intelligence/PRJournal/Vol2/No2/\#.VObyw3yUeHR 
Rhoades, L., and Eisenberger, R., (2002) Perceived Organizational Support: A Review of the Literature. Journal of Applied Psychology. 87(4), 698-714.

Rowe, G. and Frewer, L.J. (2005) A Typology of Public Engagement Mechanisms. Science, Technology and Human Values; 30(2), 251-290.

Schnackenberg, A., (2009) Measuring Transparency: Towards a greater understanding of systemic transparence and accountability Working Paper. https://weatherhead.case.edu/departments/organizational-behavior/ working Papers/WP-09-02.pdf

Schnackenberg, A. K., and Tomlinson, E. C. (2016). Organizational transparency: A new perspective on managing trust in organization-stakeholder relationships. Journal of Management, 42(7), 1784-1810. https://doi.org/10.1177/0149206314525202

Settoon, R., Bennet, N., and Liden, R. (1996). Social exchange in organizations: Perceived organizational support, leader member exchange, and employee reciprocity. Journal of Applied Psychology. 81(3). 219-227.

Shanthakumary, M.C.M.A.(2019). "Protean Career Orientation and Work Life Outcomes among Graduate Employees in Jaffna District", Unpublished PhD Thesis, University of Jaffna, Sri Lanka.

Shore, L. M., and Martin, H. J. (1989). Job satisfaction and organizational commitment in relation to work performance and turnover intentions. Human Relations, 42(7),625-638.

Siders, M.A., George, G., and Dharwadkar, R. (2001). The Relationship of internal and external commitment foci to objective job performance measures, Academy of Management Journal, 44(3),570-579.

Suliman, A., and Iles, P. (2000). Is Continuance Commitment Beneficial to Organizationsfi Commitment- Performance Relationship: A New Look. Journal of Managerial Psychology, 15(5), 407-426.

Tabachnick, B. G., and Fidell, L. S. (1996). Using multivariate statistics (3rd ed.). HarperCollins. 
Taylor, S. (1998). Employee Resourcing. London: Institute of personal development.

Towler, A. J., and Dipboye, R. L. (2003). Development of a learning style orientation measure. Organizational Research Methods, 6, 216-235.

Vance, R.J. (2006) Employee Engagement and Commitment. USA: SHRM foundation

Vorauer, J. D., and Claude, S. (1998). Perceived versus actual transparency of goals in negotiation. Personality and Social Psychology Bulletin, 24(4), 371385 .

Walumbwa, F. O., Luthans, F., Avey, J. B., and Oke, A. (2011). Authentically leading groups: The mediating role of collective psychological capital and trust. Journal of Organization Behavior, 32(1), 4-24.

Watzlawick, P., Beavin, J. H., and Jackson, D. D. (1967). Pragmatics of human communication: A study of interactional patterns, pathologies and paradoxes. New York, NY: Norton.

Williams, C. (2008). Toward a Taxonomy of Corporate Reporting Strategies. Journal of Business Communication, 45(3), 232-264. 